\title{
Bacterial abundance and biomass in response to organism- generated habitat heterogeneity in deep-sea sediments
}

\author{
Thomas Soltwedel* , Kay Vopel
}

Alfred Wegener Institute for Polar and Marine Research, PO Box 120161, 27515 Bremerhaven, Germany

\begin{abstract}
Deep-sea sediments beneath double-ridged crawling trails and around 2 sessile epibenthic species, the sea anemone Bathyphellia margaritacea Danielssen, 1890, and the demosponge Thenea abyssorum Koltun, 1959, were investigated to test whether they support a bacterial colonisation significantly higher than that of nearby control sediments. The $\mathrm{cm}$ scale features and the control sites with a virtually undisturbed sediment surface were sampled in 2 basin-like depressions in Fram Strait (Molloy Deep, 5552 m; Hayes Deep, $3668 \mathrm{~m}$ ), and on the eastern Greenland continental rise (3139 m) using a remotely operated vehicle (ROV). The uppermost $5 \mathrm{~cm}$ thick layer of the sediment around the 2 species and beneath the trails contained a significantly higher total bacterial biomass (TBB) than the control sediments. The higher TBB values resulted either from higher total numbers of sedimentary bacteria (TBN), from a higher mean biomass per cell (MBC), or both. Sediments beneath the crawling trails were inhabited by significantly more bacteria than the control sediment. The mean cell biomass of the bacteria did not differ. The TBN around the sea anemone $B$. margaritacea and in control samples were almost in the same range; the MBC around the anemones, however, was significantly higher than in the control sediments. The higher TBB in the sediment around the sponge $T$. abyssorum resulted from higher values of both TBN and MBC. Our results confirmed that small epibenthic species and crawling trails sufficiently modify the surrounding sediment-seawater interface to affect the abundance and biomass of sediment-associated biota. The biogenic structures locally increase bacterial colonisation at the sediment-water interface and thus potentially increase habitat heterogeneity for the smallest benthic organisms.
\end{abstract}

KEY WORDS: Benthic bacterial assemblages - Biogenic structures $\cdot$ Small-scale heterogeneity $\cdot$ Deep sea

Resale or republication not permitted without written consent of the publisher

Benthic organisms alter the seafloor of the deep sea in a variety of ways. They produce burrows, sediment mounds, leave feeding traces and faecal castings, and build robust structures in which to live. These biogenic sediment structures vary from millimetres to several

*E-mail: tsoltwedel@awi-bremerhaven.de centimetres in length. Deep-sea photographs show that they are common and are often the most conspicuous small-scale topographic features on the seafloor down to the greatest water depths. Due to generally low hydrodynamic energy (e.g. currents, internal waves) and low rates of sedimentation in the deep sea, biologically produced structures on the seafloor can persist over long periods of time and constitute a source of habitat heterogeneity for smaller organisms of the benthic community (see review by Gage 1996, and references therein).

The disruption of the sediment surface by the activity of motile bottom organisms may increase nutrient fluxes across the sediment-water interface (Huettel 1992), thereby stimulating the productivity of benthic micro-organisms. Projecting biogenic structures (e.g. erect agglutinating foraminifers, polychaete tubes, and sessile epibenthic organisms) might also affect sediment-inhabiting organisms. Feeding sessile animals leave faeces or perhaps remains of food organisms nearby on the sediment surface, which may locally enhance microbial growth. Any erect structure, however, modifies local patterns of flow, thereby altering particle deposition and erosion rates (Carey 1983, Eckman 1985, Vogel 1994, Witte et al. 1997, Friedrichs et al. 2000). As a result, surface-derived detrital organic matter, which is an important food source for benthic organisms, is trapped in or around biogenic structures and is thus irregularly distributed on the seafloor (Yager et al. 1993). Accumulated organic matter on the leeward side of projecting biogenic structures, in burrows, and on any biologically disrupted sediment surface is expected to affect distribution patterns of the smallest sediment-inhabiting organisms (size range: bacteria to meiofauna). Several authors have already demonstrated such effects for shallow-water habitats (Reise 1981, Thomsen \& Altenbach 1993). Aller \& Aller (1986) are the only authors to have reported enhanced 
bacterial numbers and biomasses as well as increased meiofauna abundances around biogenic structures (polychaete tubes and burrows) in deep-sea sediments.

This study aims to contribute to our understanding of the role of biologically produced habitat heterogeneity in structuring deep-sea benthic communities. Here, we present data gained from the analyses of samples taken by a targeted sampling of 3 different biogenic sources of habitat heterogeneity by means of a remotely operated vehicle (ROV).

Material and methods. Sediments beneath doubleridged crawling trails (approx. $5 \mathrm{~cm}$ wide) and around 2 epifaunal sessile species, the 2 to $3 \mathrm{~cm}$ tall sea anemone Bathyphellia margaritacea Danielssen, 1890 (Bathyphelliidae) and the 0.5 to $3 \mathrm{~cm}$ tall sponge Thenea abyssorum Koltun, 1964 (Demospongia, Choristida), were sampled at 2 basin-like depressions in Fram Strait (Molloy Deep, Hayes Deep), and at the eastern Greenland continental rise (Table 1, Fig. 1). The samples were taken by means of the French deep-diving ROV 'Victor 6000' (IFREMER/GENAVIR) from aboard RV 'Polarstern' during the polar expedition ARK XV/1 in July 1999. Sediments with a homogeneous, virtually undisturbed surface adjacent (in $\mathrm{m}$ distances) to the crawling trails and the sessile epibenthic species served as controls. The sediments were repeatedly sampled using plastic tubes $6 \mathrm{~cm}$ in diameter and 40 $\mathrm{cm}$ in length (Table 1). The uppermost $5 \mathrm{~cm}$ thick sediment layers in the tubes were subsampled by means of small syringes (1.2 and $2.0 \mathrm{~cm}$ in diameter) with cutoff anterior ends. The subsamples, 1 syringe per sediment core, were then sliced into $1 \mathrm{~cm}$ thick layers and treated separately. Each horizon was diluted 10-fold in pre-filtered $(0.2 \mu \mathrm{m})$ seawater supplemented with Formalin (4\% seawater solution) and stored. In the laboratory, the sediment samples were further diluted with distilled water, giving a final dilution of $10^{-4}$. An appropriate volume of 2 to $5 \mathrm{ml}$ was filtered onto a $0.2 \mu \mathrm{m}$ black Nuclepore polycarbonate membrane, stained with $0.1 \%$ acridine orange and washed with citrate buffer ( $\mathrm{pH}$ 4.0). Bacterial cells were counted by epifluorescence microscopy according to Meyer-Reil (1983). Volumetric determinations were conducted with the Porton grid as described by Grossmann \& Reichardt (1991). Each value for bacterial cell numbers represents the mean of 40 counted grids from a single filter.

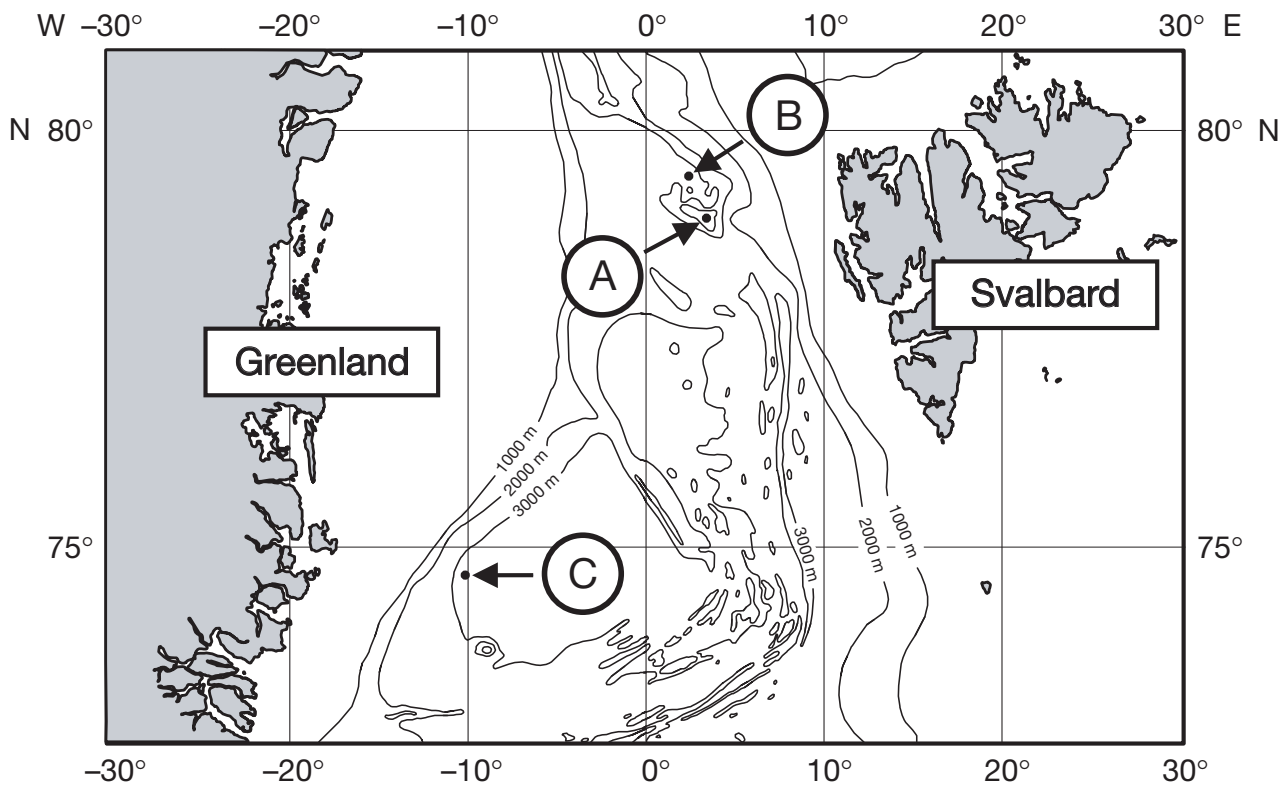

Fig. 1. Sampling sites in Fram Strait and in the western Greenland Sea: (A) Molloy Deep, (B) Hayes Deep, and (C) Eastern Greenland continental rise

Table 1. Station data, and number of biogenic structures and control sediments sampled at the different sites in the northern and western Greenland Sea

\begin{tabular}{|lcccccc|}
\hline Site & Date & Position & Depth (m) & Biogenic structure & Replicate structure & Control \\
\hline A (Molloy Deep) & 04 Jul 99 & $79^{\circ} 08.6^{\prime} \mathrm{N}, 2^{\circ} 49.5^{\prime} \mathrm{E}$ & 5552 & Tracks & 3 & 3 \\
B (Hayes Deep) & 06 Jul 99 & $79^{\circ} 28.5^{\prime} \mathrm{N}, 2^{\circ} 58.0^{\prime} \mathrm{E}$ & 3668 & Anemones & 4 & 3 \\
C (Greenland Rise) & 09 Jul 99 & $74^{\circ} 22.9^{\prime} \mathrm{N}, 10^{\circ} 18.6^{\prime} \mathrm{E}$ & 3139 & Sponges & 3 \\
\hline
\end{tabular}


For the determination of mean cell volumes, we estimated the size of 50 randomly chosen cells. Bacterial biomass was estimated using a conversion factor of 3.0

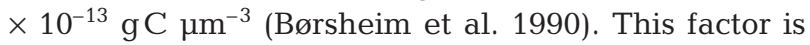
only one among a series offered by the literature, and it may be considered as fairly high. As we intend to compare biomass data only within this investigation and not with results from other authors, the conversion factor chosen will not affect the general outcome of our study.

In addition to the ROV samples, a multiple corer (MUC) (Barnett et al. 1984) was deployed at each station to collect additional sediments for a number of abiotic and biotic 'background' parameters. From each multiple corer (randomly sampled from different MUC tubes), 3 to 5 subsamples were analysed for water content (sediment porosity), chloroplastic pigments (phytodetrital matter), phospholipids (cell wall components) and particulate proteins (biomass). Sediment water contents were estimated by weight loss of wet sediment samples dried at $60^{\circ} \mathrm{C}$. Sediment-bound chlorophyll $a$ and phaeopigment concentrations were determined to quantify the input of phytodetritus to the seafloor. Chloroplastic pigments were extracted in $90 \%$ acetone and measured with a Turner fluorometer according to Shuman \& Lorenzen (1975). The bulk of the pigments registered with this method was termed chloroplastic pigment equivalents, CPE (Thiel 1978). Phospholipids (PL) were analysed specifically as indicators for 'living biomass', i.e. the bulk of the small sediment-inhabiting organisms (size range: bacteria to meiofauna). Phospholipids were determined by the method of Findlay et al. (1989) with slight modifications as described in Boetius \& Lochte (1994). According to
Dobbs \& Findlay (1993), PL concentrations may be used to calculate the total microbial biomass (TMB) in terms of organic carbon, applying a conversion factor of $100 \mu \mathrm{molP} \mathrm{g} \mathrm{C}^{-1}$. Particulate proteins (PP) were determined to estimate the bulk of the 'living' plus 'dead' biomass, i.e. organisms and the proportion of detrital organic matter in the sediments. PP, operationally defined as $\gamma$-globulin equivalents, were measured following instructions given by Greiser \& Faubel (1988).

Data are given as means \pm standard deviations. The differences between treatment and control were tested for significance based on the replicate cores using the non-parametric Mann-Whitney $U$-test at a significance level of $5 \%$ (Sachs 1992).

Results and discussion. Sampling site characteristics: The mean water content and concentrations of chloroplastic pigment equivalents, phospholipids and particulate proteins in the 5 uppermost $1 \mathrm{~cm}$ thick sediment layers of the 3 sampling sites are shown in Fig. 2. Cumulative values for these uppermost $5 \mathrm{~cm}$ are summarised in Table 2. The lowest numbers for all parameters were found at Site C (Greenland continental rise). The water content (porosity) of the sediments at all sampling sites decreased with increasing sediment depth. Highest values were determined at Site B (Hayes Deep). Although Site A (Molloy Deep) lies approx. $2000 \mathrm{~m}$ deeper than Site B, concentrations of sediment-bound pigments (indicating the flux of primary organic matter to the seafloor) were similar at both sampling sites (values for the uppermost $\mathrm{cm}$ : $\sim 3.2 \mu \mathrm{g} \mathrm{cm}^{-3}$ ). Compared to Site A, the shallower Site B exhibited a significantly higher relative proportion of intact chlorophyll $a$, indicating comparably 'fresh' phytodetrital matter on the seafloor. Phospholipid concen-

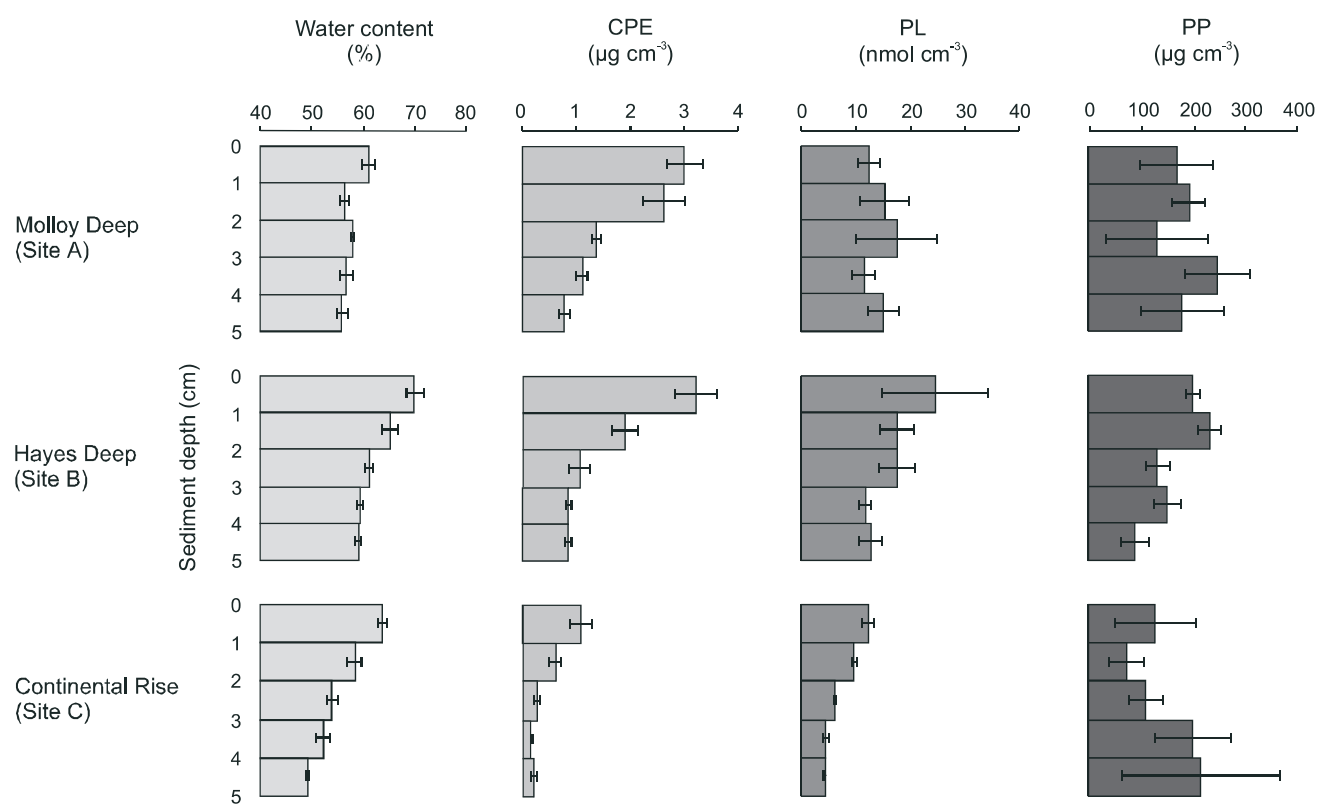

Fig. 2. Water content (\% wet weight), and concentrations of chloroplastic pigment equivalents (CPE), phospholipids (PL) and particulate proteins (PP) in the 5 uppermost $1 \mathrm{~cm}$-thick layers of control sediments 
Table 2. Water content (WC, \% wet weight) and concentrations of chlorophyll a (Chl a), phaeopigments (Phaeo), chloroplastic pigment equivalents (CPE), phospholipids (PL), and particulate proteins (PP) in the uppermost $5 \mathrm{~cm}$ of sediment at Sites A-C $($ Mean $\pm \mathrm{SD})$

\begin{tabular}{|c|c|c|c|c|c|c|}
\hline Site & WC (\%) & Chl a $\left(\mu \mathrm{g} 5 \mathrm{~cm}^{-3}\right)$ & Phaeo $\left(\mu \mathrm{g} 5 \mathrm{~cm}^{-3}\right)$ & $\mathrm{CPE}\left(\mu \mathrm{g} 5 \mathrm{~cm}^{-3}\right)$ & PL $\left(\mathrm{nmol} 5 \mathrm{~cm}^{-3}\right)$ & $\mathrm{PP}\left(\mathrm{mg} 5 \mathrm{~cm}^{-3}\right)$ \\
\hline A & $57.6 \pm 0.3$ & $0.14 \pm 0.03$ & $9.0 \pm 0.6$ & $9.1 \pm 0.6$ & $72.5 \pm 3.2$ & $0.94 \pm 0.07$ \\
\hline B & $62.8 \pm 0.8$ & $0.21 \pm 0.03$ & $7.6 \pm 0.6$ & $7.8 \pm 0.6$ & $84.2 \pm 9.0$ & $0.82 \pm 0.01$ \\
\hline $\mathrm{C}$ & $54.9 \pm 0.3$ & $0.03 \pm 0.00$ & $2.2 \pm 0.2$ & $2.3 \pm 0.2$ & $36.7 \pm 1.2$ & $0.72 \pm 0.20$ \\
\hline
\end{tabular}

trations were highest at Site B $\left(24.6 \mathrm{nmol} \mathrm{cm}^{-3}\right.$ in the uppermost $1 \mathrm{~cm}$ ), decreasing with increasing sediment depth. No similar gradient was detectable at Site A, which exhibited overall lower values, especially for the upper sediment layers (0 to $2 \mathrm{~cm}$ ). Irregular distribution patterns were also found for particulate proteins (PP) in the Molloy Deep, whereas PP concentrations in the Hayes Deep decreased with increasing sediment depth. In contrast, PP concentrations at Site C (Greenland continental rise) showed an inverted gradient. Cumulative values ( 0 to $5 \mathrm{~cm}$ ) at the 3 sites were almost in the same range $\left(0.7\right.$ to $\left.0.9 \mathrm{mg} 5 \mathrm{~cm}^{-3}\right)$. There was no relationship between indicators of phytodetrital matter (as potential food/energy source) and the bacterial data (see below), neither for absolute numbers per station, nor for distribution patterns in the sediment columns. Lowest concentrations of sediment-bound pigments at Site $\mathrm{C}$, for instance, were not reflected by comparably low bacterial numbers and biomasses. Furthermore, the mean abundance, cell biomass, and total bacterial biomass per sampling site showed no clear relationships to water depth or sediment porosity, to indicators of phytodetritus input (sediment-bound pigments), or to biomass parameters (phospholipids, particulate proteins). These results concur with several studies which also failed to show direct relationships between bacterial data, and single abiotic and biotic factors (Boetius et al. 1996, Boetius \& Damm 1998, Schewe 2001). Other authors, however, reported positive correlations between bacterial data and water depth (Deming \& Yager 1992, Soltwedel \& Schewe 1998), sediment grain sizes, organic matter availability (Dale 1974, Rublee 1982, Hansen \& Alongi 1991, Deming \& Yager 1992) as well as individual biomass parameters such as phospholipids and particulate proteins (Soltwedel et al. 2000).

Phospholipid (PL) determinations were carried out to quantify the total microbial biomass (including bacteria, fungi, yeasts, protozoans, and meiofauna) in the sediments, and to assess the relative proportion of bacterial biomass in the samples. Assuming that PL determinations provide reliable data on the total microbial biomass (TMB), then a comparison of bacterial biomass data (from direct counts and volumetric measurements; see below) with TMB values showed that the relative proportions of bacterial biomass per sampling site ranged between 15 and $40 \%$ (mean values for the upper $5 \mathrm{~cm}$ of sediment). The highest proportions were found at Site $\mathrm{C}$, the lowest at Site A. The higher availability of phytodetritus at Sites A probably promotes bacterivorous organisms (e.g. flagellates, ciliates, foraminiferans, meiofauna), as reflected in a significantly lower relative proportion of bacterial biomasses at this site. Intermediate values were found for Site B.

Molloy Deep (Site A), double-ridged trails: The total numbers and biomasses of bacteria in the uppermost $\mathrm{cm}$ and the 0 to $5 \mathrm{~cm}$ layer of sediments beneath these plane crawling trails differed significantly from nearby control sediments (Table 3, Fig. 4A). Bacterial numbers in the uppermost $5 \mathrm{~cm}$ thick sediment layer below the tracks $\left(103.2 \pm 11.0 \times 10^{8}\right.$ cells $\left.5 \mathrm{~cm}^{-3}\right)$ were $2-3$ times higher than in control sediments $(41.6 \pm 12.9$ $\times 10^{8}$ cells $5 \mathrm{~cm}^{-3}$ ). No significant differences were found for mean bacterial biomasses per cell (25.5 and $25.7 \mathrm{fg}$ $\mathrm{C}_{\text {cell }}{ }^{-1}$. Accordingly, the total bacterial biomass under the tracks $\left(256.9 \pm 38.6 \mu \mathrm{g} \mathrm{C} 5 \mathrm{~cm}^{-3}\right)$ was about 3 times higher than in control samples $(107.1 \pm 34.6 \mu \mathrm{gC}$ $5 \mathrm{~cm}^{-3}$ ). Under the trails, total bacterial numbers and biomasses decreased with sediment depth (Fig. 3); no such gradient was recorded in the control sediments. Irregular distribution patterns in the ambient sediment column were also found for biochemical biomass parameters (i.e. phospholipids, particulate proteins) in multiple corer samples from Site A (Fig. 2). Mean bacterial biomasses per cell below the animal tracks and from nearby sites showed no clear trend with increasing sediment depth. However, bacterial numbers (and consequently total bacterial biomasses) in the former were significantly higher than in the latter throughout the sediment column.

Significantly higher bacterial numbers and biomasses in the tracks are probably not caused by the accumulation of particulate organic matter since the ridges of the tracks were only a few $\mathrm{mm}$ in height. The trail ridges could potentially interact with the near-bottom flow and thus enhance the exchange of inorganic nutrients through the sediment-water interface. However, as the sediment surface along the trails is flattened and the upper millimetres compacted, such fluxes at the sediment-water interface are probably 
Table 3. Total bacterial number (TBN), mean bacterial biomass per cell (MBC) and total bacterial biomass (TBB) in the uppermost $1 \mathrm{~cm}$ thick layer of the sediment around biogenic structures and in control sediments (mean $\pm \mathrm{SD}$ ). Asterisks indicate that differences between structure and control are significant at $\mathrm{p}<0.05$

\begin{tabular}{|c|c|c|c|c|c|c|}
\hline \multirow[t]{2}{*}{ Site } & \multicolumn{2}{|c|}{ TBN $\left(10^{8}\right.$ cells $\left.\mathrm{cm}^{-3}\right)$} & \multicolumn{2}{|c|}{ MBC $\left(\right.$ fg cell $\left.{ }^{-1}\right)$} & \multicolumn{2}{|c|}{ TBB $\left(\mu \mathrm{g} \mathrm{cm}^{-3}\right)$} \\
\hline & Structure & Control & Structure & Control & Structure & Control \\
\hline A & $28.0 \pm 7.9^{*}$ & $8.2 \pm 2.9$ & $25.1 \pm 1.8$ & $24.7 \pm 0.4$ & $71.3 \pm 23.4^{*}$ & $20.2 \pm 7.2$ \\
\hline B & $16.8 \pm 4.7$ & $14.2 \pm 2.8$ & $47.5 \pm 9.3^{*}$ & $34.1 \pm 4.9$ & $76.1 \pm 11.8$ & $48.7 \pm 12.2$ \\
\hline $\mathrm{C}$ & $16.9 \pm 3.8$ & $12.5 \pm 2.4$ & $27.9 \pm 1.2$ & $28.2 \pm 4.0$ & $46.7 \pm 9.0$ & $36.3 \pm 11.8$ \\
\hline
\end{tabular}

reduced rather than enhanced. Assuming that the tracks are produced by gastropods, the higher values could be explained by enhanced microbial production in (and beneath) the organic-rich mucus released by the animals for the purposes of locomotion. Gastropod pedal mucus consists preliminary of proteins and polysaccharides (Connor 1986). Herndl \& Peduzzi (1989) have already showed that mucous trails produced by marine shallow-water gastropods are readily degradable and rapidly utilised by microheterotrophs.

Hayes Deep (Site B), Bathyphellia margaritacea: The mean total bacterial number in the sediment around this 2 to $3 \mathrm{~cm}$ tall sea anemone $\left(70.6 \pm 13.9 \times 10^{8}\right.$ cells $\left.5 \mathrm{~cm}^{-3}\right)$ and in control sediment $\left(64.2 \pm 8.1 \times 10^{8}\right.$ cells $5 \mathrm{~cm}^{-3}$ ) was almost in the same range (Fig. 4B). Significant differences were found in mean biomasses per cell $\left(49.7 \pm 4.8\right.$ and $33.9 \pm 1.6 \mathrm{fgC}$ cell $\left.^{-1}\right)$. Accordingly, the mean total bacterial biomass in the upper $5 \mathrm{~cm}$ of the sediments around the sea anemone was signifi- cantly higher than in control sediments $(343.1 \pm 47.2$ and $217.6 \pm 34.7 \mu \mathrm{gC} 5 \mathrm{~cm}^{-3}$, respectively). No significant differences were found for total bacterial biomass in the uppermost centimetre of the sediments (Table 3). The bacteria in the sediments at Site B were generally clearly bigger than in the sediments of Sites A and C. Within the sediment column, bacterial abundances, mean biomasses per cell and total bacterial biomasses at Site B gradually decreased with sediment depth (Fig. 3). When compared with the control, the mean biomass per cell (and consequently total bacterial biomasses) around the sea anemone was higher throughout the sediment column.

The sea anemone Bathyphellia margaritacea is most likely a passive filter feeder (K. Riemann-Zürneck pers. comm.). These organisms do not actively generate a flow field but passively modify local near-bottom currents. In relation to their shape, these organisms produce distinct low- and high-energy areas in their

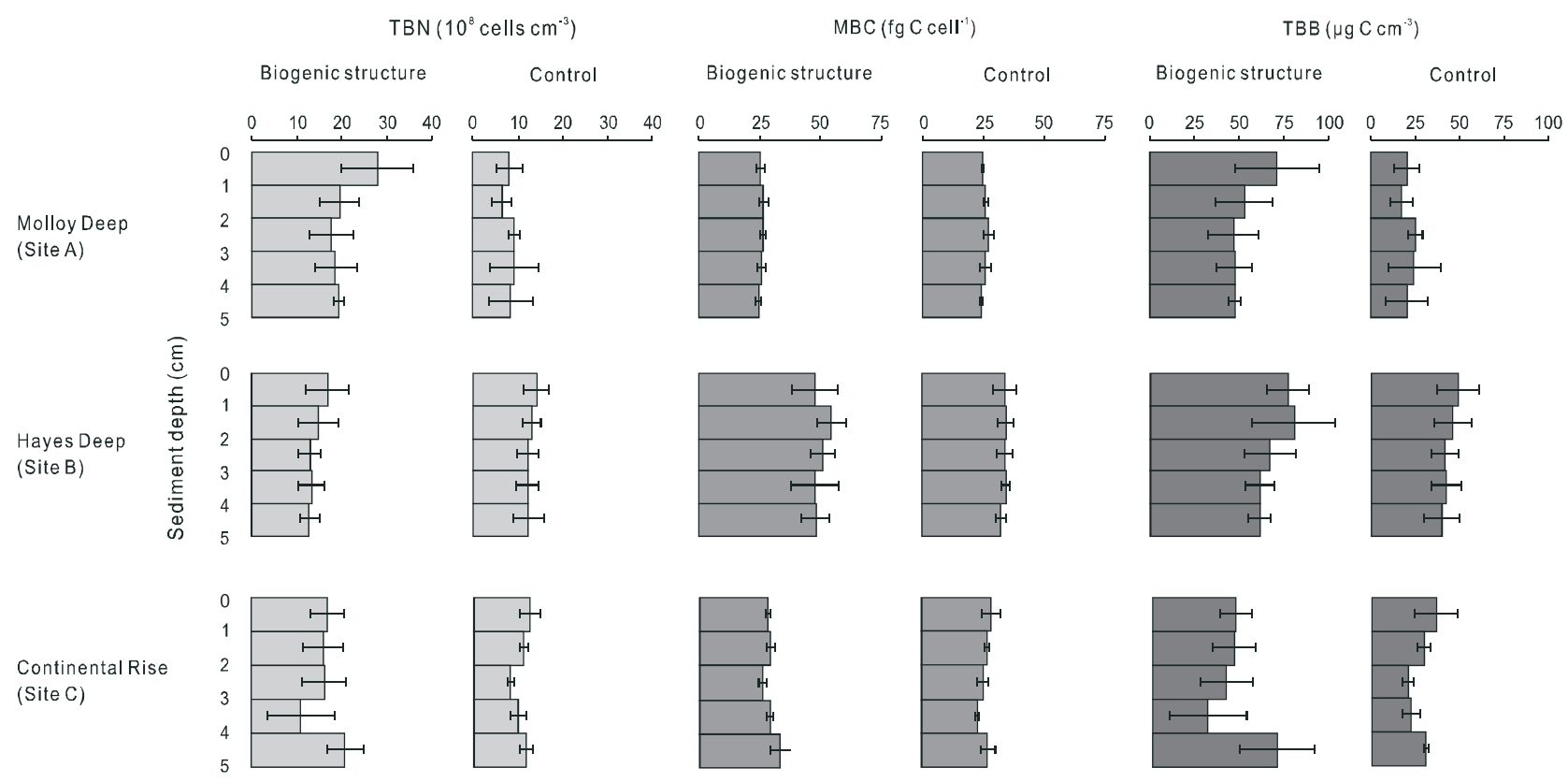

Fig. 3. Vertical distribution of total bacterial numbers (TBN), mean bacterial biomasses per cell (MBC; standard deviations indistinguishable from data point) and total bacterial biomass (TBB) in the 5 uppermost $1 \mathrm{~cm}$ thick sediment layers around biogenic structures and in control sediments 

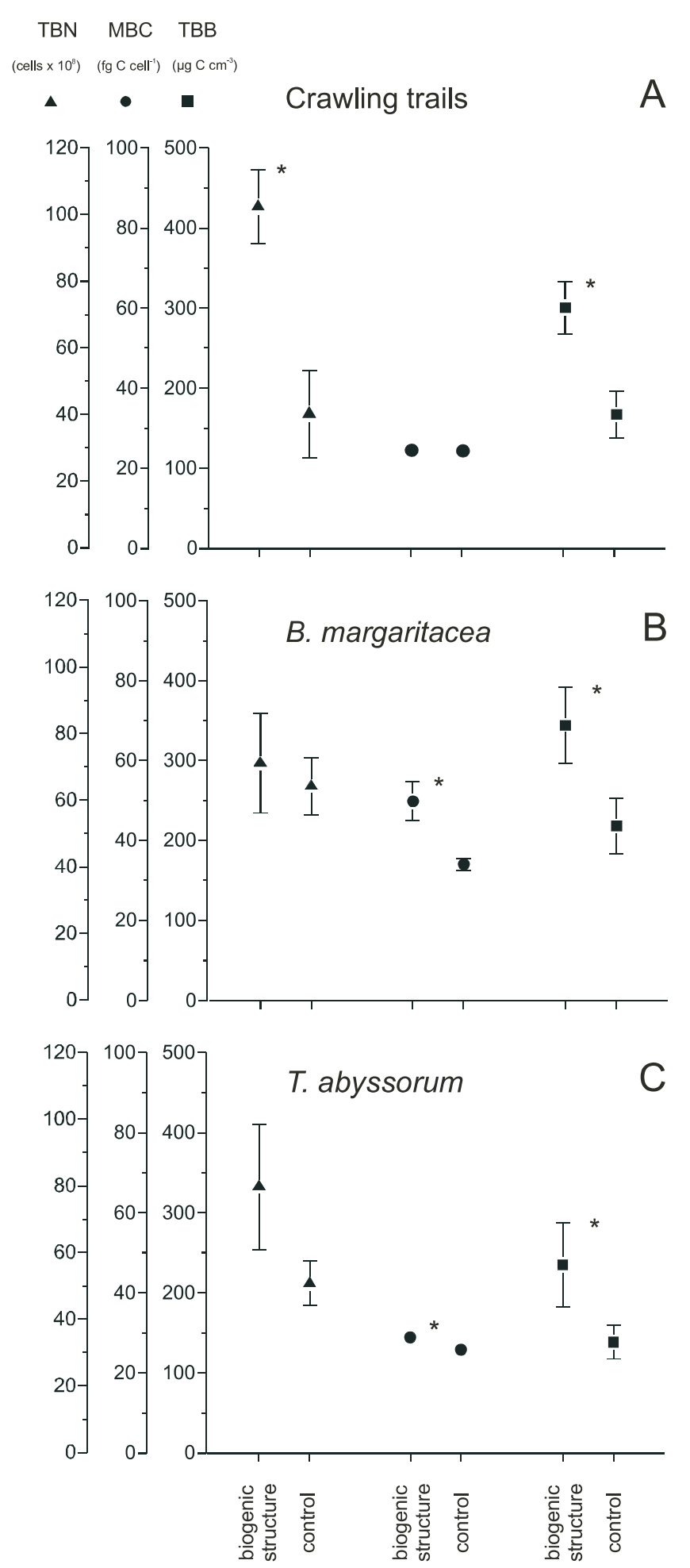

Fig. 4. Total bacterial number (TBN), mean bacterial cell biomass (MBC) and total bacterial biomass (TBB) in the uppermost $5 \mathrm{~cm}$ thick layer of control sediment and of sediments beneath (A) double-ridged crawling trails, around (B) the sea anemone Bathyphellia margaritacea, and (C) the sponge Thenea abyssorum. Asterisks indicate that the differences between structure and control are significant at $p<0.05$ close vicinity, where light particulate matter may settle or will be eroded. Subsequently, assemblages of sediment-inhabiting bacteria around those structures should also show a distinct small-scale patchiness related to food availability in those high- and low-energy areas. Our investigations confirmed significant differences for mean bacterial volumes (and consequently for total bacterial biomasses) for assemblages around B. margaritacea versus control sediments. The bacteria around the anemones are clearly bigger than those in the control, implying either a bacterial assemblage reacting through individual biomass increase, or even a bacterial community with a completely different structure.

Greenland continental rise (Site $\mathrm{C}$ ), Thenea abyssorum: Overall differences in bacterial numbers and biomasses were also found between the sediments taken around this 0.5 to $3 \mathrm{~cm}$ tall sponge and in the control samples (Fig. 4C). The mean total bacterial cell number in the former and the latter was $80.4 \pm 17.6 \times 10^{8}$ and $53.2 \pm 6.2 \times 10^{8}$ cells $5 \mathrm{~cm}^{-3}$, respectively. The mean bacterial biomass per cell (28.9 $\left.\mathrm{fgC} \mathrm{cell}^{-1}\right)$ and the

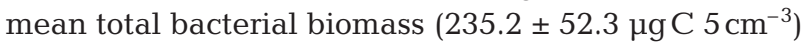
around the sponge were significantly higher than in the control sediments. The differences in cell numbers and total biomasses were only significant for cumulative values over the uppermost $5 \mathrm{~cm}$ thick sediment layer; mean values for the uppermost $1 \mathrm{~cm}$ did not differ (Table 3). Within the $5 \mathrm{~cm}$ columns, the lowest bacterial abundances, mean biomasses per cell, and total bacterial biomasses were found at intermediate depths (3 to $4 \mathrm{~cm}$ ) for both sediments (Fig. 3). Again increasing values in the 4 to $5 \mathrm{~cm}$ depth correspond to increasing concentrations in particulate proteins of deeper layers (see above).

The demosponge Thenea abyssorum dominates the poriferan communities of the Greenland-Iceland-Norwegian Seas (Barthel \& Tendal 1993) and, therefore, is supposed to play a major role in exchange processes at the sediment-water interface. The species lives half buried in the sediment, anchored with a long spicule root tuft, with the incurrent and excurrent openings just above the surface (Barthel \& Tendal 1993). The demosponge mediates the deposition of very finegrained, laterally transported particles by extracting drifting particles from the bottom water (up to $6 \mu \mathrm{m}$ in diameter); after digestion these are ejected as pellets measuring up to 50 to $100 \mu \mathrm{m}$ (Witte 1996, Witte et al. 1997). Furthermore, sponges increase sediment roughness, and affect sediment deposition and erosion passively by being obstacles for bottom currents. Nearbottom flow can be disrupted as far as $14 \mathrm{~cm}$ downstream and several cm laterally from the species (Witte et al. 1997). All these facts could explain the differences in the mean total number and cell biomass of bacteria in the upper $5 \mathrm{~cm}$ of sediment. 
General considerations. Simple ex situ flume experiments already demonstrated that local flow perturbations, e.g. by protruding animal-tube mimics or sessile epifaunal organisms, can cause an irregular distribution of organic matter around the structures (Carey 1983, Eckman 1985, Ziebis 1992, Witte et al. 1997, Friedrichs et al. 2000). Benthic organisms react to such patchy distributions of food particles, as confirmed by Reise (1981), and Thomsen \& Altenbach (1993) for shallow-water, and by Aller \& Aller (1986) for deep-sea habitats. In the past, biogenic structures were sampled by subsampling box corer samples with small tubes. In this study, the use of a remotely operated vehicle allowed the precise sampling of biologically produced structures on the seafloor. Nevertheless, the subsamples were collected without knowing whether we hit high-energy or low-energy areas (i.e. lee or luff from any obstacle) in the near-bottom current field. Microscale variations in bacterial abundances or biomasses around individual structures, however, are probably levelled out between the replicates, still allowing general statements about the effects of the biogenic structures. Later studies should consider micro-scale flow measurements to identify erosion and sedimentation areas around biogenic structures.

To understand the response of bacteria to benthic heterogeneity additional investigations should be taken into account. The analysis of nutrient concentrations (particulate and dissolved organic matter) around biogenic structures and in control sediments could be of interest. Information on bacterial activity (production, respiration) could aid understanding the role of bacteria and the bacterial response in these habitats. Future investigations should also consider the relative proportion of active and dormant cells around biogenic structures and in control samples, and genetic studies on the bacterial composition are needed to allow statements on diversity differences between bacterial assemblages around those structures and in ambient sediments.

Although lacking a number of additional pieces of information as named above, our study clearly demonstrated effects of biogenic structures at small scales, revealing significant differences between bacterial data from around biologically produced structures and from ambient, undisturbed sediments.

Acknowledgements. The authors thank the operational team of the remotely operated vehicle 'Victor 6000' (IFREMER/ GENAVIR) and the crew of RV 'Polarstern' for their helpful support during the expedition ARK XVI/1 in summer 1999, and Anja Pappert, Melanie Weber and Christiane Hasemann for technical assistance. Karin Riemann-Zürneck and Susanne Gatti helped to identify the sea anemones and sponges sampled for this study. We also thank Michael Stachowitsch, Karen von Juterzenka and 4 anonymous refer- ees for valuable comments on the manuscript. This is publication awi-n10096 of the Alfred Wegener Institute for Polar and Marine Research.

\section{LITERATURE CITED}

Aller JY, Aller RC (1986) Evidence for localized enhancement of biological activity associated with tube and burrow structures in the deep-sea sediments at the HEBBLE site, western North Atlantic. Deep-Sea Res 33(6):755-790

Barnett PRO, Watson J, Connelly D (1984) A multiple corer for taking virtually undisturbed samples from shelf, bathyal and abyssal sediments. Oceanol Acta 7:399-408

Barthel D, Tendal OS (1993) The sponge association of the abyssal Norwegian-Greenland Sea: species composition, substrate relationships and distribution. Sarsia 78:83-96

Boetius A, Damm E (1998) Benthic oxygen uptake, hydrolytic potentials and microbial biomass at the Arctic continental slope. Deep-Sea Res 45(2/3):239-275

Boetius A, Lochte K (1994) Regulation of microbial enzymatic degradation of OM in deep-sea sediments. Mar Ecol Prog Ser 104:299-307

Boetius A, Scheibe S, Tselepides A, Thiel H (1996) Microbial biomass and activities in deep-sea sediments of the Eastern Mediterranean: trenches are benthic hotspots. DeepSea Res 43(9):1439-1460

Børsheim KY, Bratbak G, Heldal M (1990) Enumeration and biomass estimation of planktonic bacteria and viruses by transmission electron microscopy. Appl Environ Microbiol $56: 352-356$

Carey DA (1983) Particle resuspension in the benthic boundary layer induced by flow around polychaete tubes. Can J Fish Aquat Sci 40:301-308

Connor VM (1986) The use of mucus trails by intertidal limpets to enhance food resources. Biol Bull Mar Biol Lab, Woods Hole 171:548-564

Dale NG (1974) Bacteria in intertidal sediments: factors related to their distribution. Limnol Oceanogr 19:509-518

Deming JW, Yager PL (1992) Natural bacterial assemblages in deep-sea sediments: towards a global view. In: Rowe GT, Pariente V (eds) Deep-sea food chains and the global carbon cycle. Kluwer Academic Publishers, Dordrecht, p 11-27

Dobbs FC, Findlay RH (1993) Analysis of microbial lipids to determine biomass and detect the response of sedimentary microorganisms to disturbance. In: Kemp PF, Sherr BF, Sherr EB, Cole JJ (eds) Handbook of methods in aquatic microbial ecology. Chapter 40. CRC Press, Boca Raton, FL

Eckman JE (1985) Flow disruption by an animal tube mimic affects sediment bacterial colonization. J Mar Res 43(2): 419-435

Findlay RH, King GM, Watling L (1989) Efficiency of phospholipid analysis in determining microbial biomass in sediments. Appl Environ Microbiol 55:2888-2893

Friedrichs M, Graf G, Springer B (2000) Skimming flow induced over a simulated polychaete tube lawn at low population densities. Mar Ecol Prog Ser 192:219-228

Gage JD (1996) Why are there so many species in deep-sea sediments. J Exp Mar Biol Ecol 200:257-286

Greiser N, Faubel A (1988) Biotic factors. In: Higgens RP, Thiel $\mathrm{H}$ (eds) Introduction to the study of meiofauna. Smithsonian Institution Press, Washington DC, p 79-114

Grossmann S, Reichardt W (1991) Impact of Arenicola marina on bacteria in intertidal sediments. Mar Ecol Prog Ser 77: 85-93

Hansen JA, Alongi DM (1991) Bacterial productivity and benthic standing stocks in a tropical coastal embayment. Mar 
Ecol Prog Ser 68:301-310

Herndl GJ, Peduzzi P (1989) Potential microbial utilization rates of sublittoral gastropod mucus trails. Limnol Oceanogr 34:780-784

Huettel M, Gust G (1992) Impact of bioroughness on interfacial solute exchange in permeable sediments. Mar Ecol Prog Ser 89:253-267

Meyer-Reil LA (1983) Benthic response to sedimentation events during autumn to spring at a shallow water station in the western Kiel Bight. Mar Biol 77:247-256

Reise K (1981) High abundance of small zoobenthos around biogenic structures in tidal sediments of the Wadden Sea. Helgol Meeresunters 34:413-425

Rublee PA (1982) Seasonal distribution of bacteria in salt marsh sediments in North Carolina. Estuar Coast Shelf Sci $15: 67-74$

Sachs L (1992) Angewandte Statistik: Anwendung statistischer Methoden. Springer Verlag, Berlin

Schewe I (2001) Small-sized benthic organisms of the Alpha Ridge, central Arctic Ocean. Int Rev Hydrobiol 8(3):315-333

Shuman FR, Lorenzen CF (1975) Quantitative degradation of chlorophyll by a marine herbivore. Limnol Oceanogr 20: 580-586

Soltwedel T, Schewe I (1998) Activity and biomass of the small benthic biota under permanent ice-coverage in the

Editorial responsibility: Otto Kinne (Editor),

Oldendorf/Luhe, Germany central Arctic Ocean. Polar Biol 19(1):52-62

Soltwedel T, Mokievsky V, Schewe I (2000) Benthic activity and biomass on the Yermak Plateau and in adjacent deepsea regions northwest of Svålbard. Deep-Sea Res 47(9): 1761-1785

Thiel H (1978) Benthos in upwelling regions. In: Boje $\mathrm{R}$, Tomczak M (eds) Upwelling ecosystems. Springer, Berlin, p 124-138

Thomsen L, Altenbach AV (1993) Vertical and areal distribution of foraminiferal abundance and biomass in microhabitats around inhabited tubes of marine echiurids. Mar Micropaleontol 20:303-309

Vogel S (1994) Life in moving fluids. The physical biology of flow. Princeton University Press, Oxford

Witte U (1996) Seasonal reproduction in deep-sea sponges triggered by vertical particle flux? Mar Biol 124:571-581

Witte U, Brattegard T, Graf G, Springer B (1997) Particle capture and deposition by deep-sea sponges from the Norwegian-Greenland Sea. Mar Ecol Prog Ser 154:241-252

Yager PL, Nowell ARM, Jumars PA (1993) Enhanced deposition to pits: a local food source for benthos. J Mar Res 51: 209-236

Ziebis W (1992) Experimente im Strömungskanal zum Einfluß der Makrofauna auf den bodennahen Partikeltransport. Vol 37. Ber Sonderforschungsbereich 313, Universität Kiel

Submitted: December 22, 2000; Accepted: May 8, 2001

Proofs received from author(s): August 10, 2001 